ROCZNIKI HUMANISTYCZNE

Volume 66, issue $3-2018$

SELECTED PAPERS IN ENGLISH

DOI: http://dx.doi.org/10.18290/rh.2018.66.3-4e

REV. WINCENTY MYSZOR

\title{
THE INCARNATE LOGOS IN GNOSTIC THEOLOGY
}

In popular Gnostic approaches to Christology, including the approach to the "incarnation" of the Logos, it is presented in a simplified way as Docetic Christology. New source texts and above all the writings of Christian Gnostics from the Nag Hammadi library, confirm the existence of Christology which Adolf Harnack called "Zwei-Naturen-Lehre."1 The Christian Gnostics tried to interpret ecclesiastical teaching in the spirit of their theology and noticed the duality in the figure of the Saviour, his divine and human aspects. Their writings sometimes preserve the motifs of early Christian theology, abandoned by ecclesiastical theology along with the rejection of Gnosticism as heresy. The Docetic version of the Gnostic Christology was one of many interpretations, and interestingly, in the light of the teaching of the original Gnostic literature, not at all the most representative. From among a number of approaches, I would like to present the one that we can find in Tractatus Tripartitus (=TractTrip), a Valentinian treatise from Nag Hammadi Codex I. ${ }^{2}$

Rev. Prof. Dr. Hab. WincENTY MYSZOR - professor emeritus at the University of Silesia in Katowice (2001-2011), formerly Warsaw Theological Academy/ Cardinal Stefan Wyszyński University in Warsaw (1969-2001); address for correspondence-e-mail: wincenty2myszor@onet.pl

The Polish version of the article was published in Roczniki Humanistyczne vol. 58-59, issue 3 (2010-2011).

${ }^{1}$ Cf. Dietrich Voorgang, Die Passion Jesu und Christi in der Gnosis (Frankfurt am Main: Peter Land, 1991), 252: "Nicht der Doketismus (im strengen Sinn) ist das Charakteristische der gnostischen Christologie, sondern die Zwei-Naturen-Lehre, d.h. die Unterscheidung zwischen Jesus und Christus."

${ }^{2}$ I adopted this approach from: Einar Thomassen, The Spiritual Seed, The Church of the Valentinians," [Nag Hammadi and Manichaean Studies 6] (Leiden: Brill, 2006), 47-52; English quotes after the translation by Harold W. Attridge and Dieter Mueller (http://www.earlychristian 
Below I present the most important testimonies from this treatise:

He it is who was our Savior in willing compassion, who is that which they were. For it was for their sake that he became manifest in an involuntary suffering. They became flesh and soul, that is, eternally which (things) hold them and with corruptible things they die. And as for those who came into being, the invisible one ${ }^{3}$ taught them invisibly about himself. Not only did he take upon «himself» the death of those whom he thought to save, but he also accepted their smallness to which they had descended when they were «born» in body and soul. (He did so) because he had let himself be conceived and born as an infant, in body and soul. ${ }^{4}$

The Saviour's suffering is equivalent to his adopting the body and the soul. The Gnostic author seems to dispute or at least refer to the view that the Saviour accepted death in the salvific sense. The Saviour is freely suf-

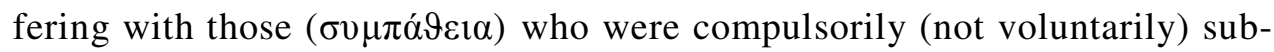
jected to suffering when they became flesh and soul, i.e. when they were created as mortals. The identification of the incarnation and suffering of the Saviour, i.e. the indication of the final consequences of the incarnation, referred to the traditional ecclesiastical teachings. The connection with the Gnostic theology is indicated by the expression about the "invisible" man whom became the Saviour and who taught his chosen ones about himself in an "invisible" way. ${ }^{6}$ To find the coherence between these, it is necessary to discover the link between the expressions "to become flesh" and simultaneously be "invisible" and to teach in an "invisible" manner. Perhaps this should be understood in such a way that, while being flesh, he concealed his

writings.com/text/theodotus.html). References given also to the Polish translation in Biblioteka z Nag Hammadi. Kodeksy I II, translated and commentary by Wincenty Myszor, [Studia Antiquitatis Christianae, Series Nova 7] (Katowice: Księgarnia św. Jacka, 2008), 87-166 (henceforth: Biblioteka).

${ }^{3}$ This may also mean that the Saviour was invisible like God: Einar THOMASSEN, Le Traité Tripartite, Bibliothèque copte de Nag Hammadi. [Section "Textes" 19] (Québec: Presses de l'Université Laval, 1989), 423 [henceforth referenced as: Einar THOMASSEN, Le Traité]: "c'est-àdire qui possède la semence spirituelle"; cf. 105, 24-25.

${ }^{4}$ Tractatus Tripartitus (= TractTrip), NHC I, pp. 113, 32-115, 12.; cf. Biblioteka 123. English translation by Harold W. Attridge and Dieter Mueller (http://www.earlychristianwritings.com/text /tripartite.html).

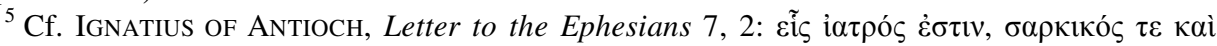

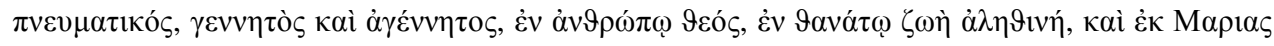

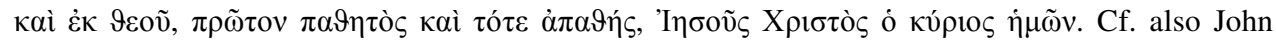
Norman D. Kelly, Poczatki doktryny chrześcijańskiej (Warszawa: PAX, 1988), 113-114.

${ }^{6}$ It lies in the nature of the one who instructs, and of those who are instructed. The Logos placed in the spiritual part of men the ability to accept revelation. See Einar THOMASSEN, Le Traité, $423 \mathrm{cf}$. TractTrip, 101, 16-28; 102, 32; 104, 33-34 and IrenaEus, AH (=Adversus Haereses), I, 5, 6. 
spiritual nature, but taught about his true invisible existence in a manner appropriate to it, i.e. in a spiritual way, without words pertaining to senses or observable actions. How did the Gnostic author understand that the Saviour appeared in the mortal body ("accepted their death"), took upon himself the "humiliation" of the created beings, and at the same time taught in an invisible way about his invisible being, his divine pre-existence? This view of the Gnostic Christians can also be linked to the ecclesiastical teaching.

It seems that we must look for the differences between Gnostic science and ecclesiastical teaching elsewhere. According to Tractatus Tripartitus, the prophets heralded the coming of the Saviour in different ways and with a varying degree of details they pointed to different sources of prophetic inspiration:

\begin{abstract}
Sometimes the prophets speak about it as if it will be. Sometimes (it is) as if the Savior speaks from their mouths, saying that the Savior will come and show favor to those who have not known him. They have not all joined with one another in confessing anything, but each one, on the basis of the thing from which he received power to speak about him, and on the basis of the place which he saw, thinks that it is from it that he will be begotten ${ }^{7}$, and that he will come from that place. Not one of them knew whence he would come nor by whom he would be begotten, but he alone is the one of whom it is worthy to speak, the one who will be begotten and will suffer. ${ }^{8}$
\end{abstract}

The prophets did not know the origin of the Saviour, but agreed that he would be born in the flesh and that he would suffer. The prophets did not know his pre-existence: "Concerning that which he previously was and that which he is eternally - an unbegotten, impassible one from the Logos, who came into being in flesh—he did not come into their thought." Although the prophets foretold the suffering of the Logos, they did not know the Logos as a being pre-existing in God, as being unborn and incapable of suffering. The prophets foretold his coming in the flesh, his suffering and death, but they did not know what the invisible Logos was to reveal in an "invisible" manner, i.e. the mysteries of his being, that he was "unbegotten" and "unable to suffer." For the Saviour, "Among all the others who shared in them, and those who fell and received the light, he came into being exalted, because he

\footnotetext{
${ }^{7}$ According to Einar ThOMASSEn, Le Traité, 420, the prophets were inspired by the powers of the spiritual hierarchy, according to the place of origin of the given inspiration in the hierarchical system.

8 TractTrip, 113, 15-33; cf. Biblioteka, 122.

9 TractTrip, 113, 34-114, 1; cf. Biblioteka, 122.
} 
had let himself be conceived without sin, stain and defilement. He was begotten in life, being in life." 10 The Saviour received flesh and soul, caused his own conception, being himself "without sin" and "without defilement," and thus manifested himself as "exalted" in the sense of being part of God. He appeared "to those who fell" as light. Upon manifesting himself as the exalted and the light, the Saviour made them capable of accepting the light or, more accurately, revealed their hidden capacity to accept salvific teaching. For his mission, i.e. the salvation of those who accept his teachings, he was equipped with adequate means. The Father commanded (him) to reveal the salvation and that through him (i.e. the Logos) the promise would be fulfilled and (therefore the Saviour) was endowed with all the instruments for the descent into this life, for he descended with their help. ${ }^{11}$ The Prophets foretold him: "And this is the account which they received an impulse to give concerning his flesh which was to appear. They say that it is a production from all of them, ${ }^{12}$ but that before all things it is from the spiritual Logos, who is the cause of the things which have come into being, from whom the Savior received his flesh." 13 The "spiritual Logos" created the flesh of the Saviour. The Logos, which in Tractatus Tripartitus appears as creative Wisdom (this is Sophia in other Valentinian treatises), gave the Saviour a body in the area of his action, i.e. in the created world. It follows that in his essence, the Saviour came from a higher region, from the zone of God, where he was called Name, or Son. ${ }^{14}$ The prophets did not have this knowledge that the Saviour is the Son of God; they foretold his coming only in the flesh. The Gnostic teachings on the view that the prophets foretold the acceptance of the body by the Saviour that comes from the spiritual Logos are also confirmed by the statements of other Valentinians.

First of all, the "Saviour" clothed upon himself the seed of the "One who gave birth," without being a part of it; He had it in his power. This seed was gradually shaped by gnosis. Having reached the Place, Jesus found Christ, who had been preached before as the one who would be the cover "for the Saviour," whom the

\footnotetext{
${ }^{10}$ TractTrip, 115, 11-18; cf. Biblioteka, 123.

${ }^{11}$ TractTrip, 114, 19-23; cf. Einar ThOMASSEn, Le Traité, 422: "Organe est entendu au sens d'organes corporels; la sphère du Logos fournit au Sauveur les structures physiques nécessaires à l'existence corporelle."

${ }^{12}$ The Saviour's body is "the creation of all of them," i.e. of those who make up his bodythe Church. The reunification of the Saviour with his Church-body took place in the area of Logos; cf. comments Einar ThOMASSEN, Le Traité, 421.

${ }^{13}$ TractTrip:, 114, 2-8; cf. Biblioteka, 122.

${ }^{14}$ Cf. remarks in: Einar Thomassen, Le Traité, 421.
} 
Prophets of the Law heralded as the "image" of the Saviour. But even this mental Christ, whom the "Saviour" put on, was invisible; and this was necessary for Him when he came into the world to live here, to be seen here and to carry a sensing body. The body was therefore woven for him from an invisible mental substance; the body descended into this sensory world owing to the power of divine preparation. ${ }^{15}$

The Gnostic author of this statement speaks of the Saviour's mental body, while Tractatus Tripartitus indicates that the Saviour's body was spiritual. ${ }^{16}$ According to the Valentinians, the Saviour had some kind of mental or spiritual body, which allowed Him to operate in the sensory world. He therefore had two "natures": divine (the Son of God) and human (the "flesh").

The suffering and death of the Saviour in the world of "body and soul" in the Gnostic sense is a reflection of "suffering" in the spiritual world, in the divine Totality. The idea of the suffering of the Logos is related to the Son's going beyond the limit of the divine Totality $(\pi \lambda \dot{\varepsilon} \rho \omega \mu \alpha) .{ }^{17}$ The Son, going beyond the Totality, enables the aeons (beings of God's Totality) to know the Father. The desire to know the Father (i.e. God) is also connected with suffering. The Son, as the divine Logos, suffers with the aeons seeking God, and by sharing this "suffering," he leads the aeons to union with God. The Son also suffers in case of the fall of one of the aeons who has gone beyond the Totality. In Tractatus Tripartitus the fall of this eon was described as the fall of Wisdom (Sophia) ${ }^{18}$ similarly to the fall in other Valentinian descriptions. In Tractatus Tripartitus, the fall and salvation are attributed to the Logos. ${ }^{19}$ When the sent Son-Logos revealed himself to the fallen Logos, ${ }^{20}$ he

\footnotetext{
${ }^{15}$ Excerpts of Theodotus, 59; cf. KLEMENS AL. Wypisy z. Theodota, based on the Polish translated by Piotr Siejkowski (Kraków: WAM, 2001), 64.

${ }^{16}$ On that basis E. Thomassen concludes that Tractatus Tripartitus is an example of the Eastern type of Valentinianism (Einar Thomassen, Le Traité, 14 f.).

${ }^{17} \mathrm{He}$ extended himself, and what he extended, he gave as their (i.e. aeons) fortification and place for the Totality, which is simultaneously his name: "the one by whom," since by this title he is the Father of Totality, by taking up his suffering for those who exist: TractTrip, 65, 4-12), cf. Biblioteka, 96.

${ }^{18}$ See Jan ZandeE, "Die Person der Sophia in der vierten Schrift des Codex Jung," in Le origini dello gnosticismo, edited by Ugo Bianchi (Leiden: Brill, 1967), 203-214; Wincenty Myszor, Anapausis w teologii chrześcijańskich gnostyków (Warszawa: Akademii Teologii Katolickiej, 1984), 83-89.

${ }^{19}$ The treatise assigns to the Logos many different functions. They are not always decipherable in the intricate text of Tractatus Tripartitus. The link between the Logos and the creation of a visible world, i.e. the Gnostic idea of collapse, seems to be clear. The fallen Logos needed salvation, or return to the divine Totality. To this end, God sends the "Son," who becomes part of the "converted" Logos, but also receives the name of the Logos.
} 
helped it return to God through the union with him. According to the Christian Gnostics, the suffering of the Son/Logos occurs both beyond and within the Totality itself. Beyond the Totality - at the level of effects, i.e. by the mere existence as body and soul; within the Totality — at the level of seeking knowledge of God, or in the dispersion of the aeons that seek unity in God. The suffering of the Logos in its pre-existence (the aeons seeking the Father in the divine Totality and the fall of the aeon of the "Logos" beyond the Totality) is an announcement or an image of what is happening in the created world, i.e. in the sphere of "body" and "soul."

The incarnation of the Son-Logos is manifested most clearly through his participation in suffering (of the body and soul). According to Tractatus Tripartitus, with the Saviour "fight the archons, the rulers of the world, who did not know that the Son of God is the master of everything and saviour, and did not turn away from their inclination to anger and doing evil deeds." 21

And even more (for) wickedness in doing to the Lord things which were not fitting, which the powers of the left ${ }^{22}$ did to him, even including his death. They persevered saying, "We shall become rulers of the universe, if the one who has been proclaimed king of the universe is slain," ${ }^{23}$ (they said this) when they labored to do this, namely the men and angels who are not from the good disposition of the right ones but from the mixture. ${ }^{24}$

In Tractatus Tripartitus we find clear allusions to the ecclesiastical profession of faith about Jesus Christ, featuring ecclesiastical concepts connected with the theology of incarnation.

They abandoned their gods whom they had previously worshipped, and the lords who are in heaven and on earth. Before he had taken them up, and while he was still a child, they testified that he had already begun to preach. And when he was in the tomb as a dead man the angels thought that he was alive, receiving life from the one who had died. ${ }^{25}$

\footnotetext{
20 "For he revealed himself to him within him, since he is with him, is a fellow sufferer with him, gives him rest little by little, makes him grow, lifts him up, gives himself to him completely for enjoyment from a vision" (TractTrip, 90, 4-11; cf. Biblioteka, 108). The idea of the fall of the Logos in Tractatus Tripartitus corresponds to the idea of the fall of Sophia in other Valentinian writings.

${ }^{21}$ TractTrip, 120, 35-121, 4; cf. Biblioteka, 126.

${ }^{22}$ These were the terms used by the Valentinians for "sense-driven" people who rejected the Saviour's call for conversion.

${ }^{23}$ TractTrip, 121, 12-17.

${ }^{24}$ TractTrip, 122, 5 f.; cf. Biblioteka, 126.

${ }^{25}$ TractTrip, 133, 27-134, 2; cf. Biblioteka, 133
} 
It seems that this refers to the Christians belonging to the Church, who have borne witness to the Saviour's teaching, death and ascension. The Saviour is someone who died, gave life to angels. The term "angels" may refer to both the Christians in the Church and the angels in the divine Totality. Salvation, similarly to the "suffering" of the Saviour, takes place on the level of the divine Totality.

\begin{abstract}
Not only do humans need redemption, but also the angels, too, need redemption, along with the image and the rest of the Pleromas of the aeons and the wondrous powers of illumination. So that we might not be in doubt in regard to the others, even the Son himself, who has the position of redeemer of the Totality, needed redemption as well- he who had become man - since he gave himself for each thing which we need, we in the flesh, who are his Church. Now, when he first received redemption from the word which had descended upon him, all the rest received redemption from him, namely those who had taken him to themselves. ${ }^{26}$
\end{abstract}

The statements by the Gnostic author of Tractatus Tripartitus allow us to look for an allusion to the ecclesiastical confession, but at the same time, they reveal certain specificity of the Valentinian theology of incarnation. If redemption (Coptic cwte 'redemption' corresponds to $c w t y r$ and refcwte 'saviour, redeemer') extends to all beings: angels, aeons and men, which can be an elaboration of the ecclesiastical thought of "universal salvation," the mention that even the Son, who is established as a model for the redemption of the Totality, [requires] the redemption, appears as specifically Gnostic. This thought reminds us of the old hypothesis in the study of Gnosticism, the idea of salvator salvandus/ salvatus. ${ }^{27}$ The solution to this paradoxical mystery seems to lie in the specific Gnostic concept of the Saviour's "body." The body are those who accepted the Saviour: "we who are in the flesh, we who are His Church." It is the Church-body of Christ, which exists in the pre-existence, as the Church united with him in the divine Totality, and the Church-body in the world, in which the Saviour proclaims salvation, i.e. the people who received him (as "pneumatics" or "psychics") and thus form his body ${ }^{28}$ Salvation means union, entering into the "body" of the Saviour. The

\footnotetext{
${ }^{26}$ TractTrip, 124, 25-125, 8; cf. Biblioteka, $128 \mathrm{f}$.

${ }^{27}$ Carsten Colpe (Die religionsgeschichtliche Schule. Darstellung und Kritik ihres Bildes vom gnostischen Erlösermythos (Göttingen: Vandenhoeck und Ruprecht, 1961), $173 \mathrm{ff}$.) showed that this abbreviation summarizes the dramatic elements of the Gnostic myth-the Saviour cannot save without being previously in the state of "salvation" himself.

${ }^{28}$ Cf. Wincenty MYszor, ““"Ekklesia” i "Kościół” w ujęciu gnostyków II i III wieku,” Verbum Vitae 6 (2004): 185-203.
} 
fall is drifting apart from the union with God. If the idea of fall and salvation in Tractatus Tripartitus concerns the same figure, i.e. "Logos" (analogous to "Sophia" in other Valentinian treatises), the Saviour is the "Son-Logos" united with God, who received the body (pneumatic and psychic), i.e. the Gnostics who united with him. The process of "fall" and "salvation" in Gnostic theology has a cosmic dimension. The anthropological approach points to the freedom of the created beings (angels and people), i.e. the question of guilt and freeing them from guilt. It seems that the author of Tractatus Tripartitus adopted the ecclesiastical terminology of incarnation, but he preached something else in its interpretation. This is how the interpretation of the Gnostics was evaluated by the best expert in the second century: "Now we have repeatedly shown that the incarnate Word of God was suspended upon a tree, and even the very heretics do acknowledge that He was crucified." ${ }^{29}$ The Gnostics adopted the formula of the Incarnate Logos, explained it and included it in the system of a different theology.

\section{BIBLIOGRAPHY}

Biblioteka z Nag Hammadi. Kodeksy I II. Translated and commentary by Wincenty Myszor. [Studia Antiquitatis Christianae, Series Nova 7]. Katowice: Księgarnia św. Jacka, 2008.

ColPE, Carsten. Die religionsgeschichtliche Schule. Darstellung und Kritik ihres Bildes vom gnostischen Erlösermythos. Göttingen: Vandenhoeck und Ruprecht, 1961.

Klemens AleksandRyjski. Wypisy z Theodota, translated by Piotr Siejkowski. Kraków: WAM, 2001.

MYszoR, Wincenty. Anapausis w teologii chrzeœcijańskich gnostyków. Warszawa: Akademia Teologii Katolickiej, 1984.

Myszor, Wincenty. ““"Ekklesia” i "Kościół” w ujęciu gnostyków II i III wieku.” Verbum Vitae 6 (2004): 185-203.

Thomassen, Einar. Le Traité Tripartite, Bibliothèque copte de Nag Hammadi. [Section "Textes" 19]. Québec: Presses de l'Université Laval, 1989.

Thomassen, Einar. The Spiritual Seed, The Church of the Valentinians. [Nag Hammadi and Manichaean Studies 6]. Leiden: Brill, 2006.

Voorgang, Dietrich. Die Passion Jesu und Christi in der Gnosis. Frankfurt am Main: Peter Land, 1991.

ZANDEE, Jan. "Die Person der Sophia in der vierten Schrift des Codex Jung." In Le origini dello gnosticismo, ed. Ugo Bianchi, 203-214. Leiden: Brill, 1967.

\footnotetext{
29 “Quoniam autem ipsum Verbum Dei incarnatum suspensum est super lignum, per multa ostendimus, et ipsi autem haeretici crucifixum confitentur" (IRENAEUS, AH, V, 18.1).
} 


\section{THE INCARNATE LOGOS IN GNOSTIC THEOLOGY}

\section{Summary}

The popular version of Gnostic Christology in textbooks presents it as a Docetic Christology. The new texts by Christian Gnostics, uncovered in Nag Hammadi, prove that Gnostic Christology was first and foremost the Christology of the Church. It seems thus that Adolf Harnack's term "the doctrine of two natures" describing the Gnostic approach is correct. The article quotes examples of Gnostic utterances from Tractatus Tripartitus of Nag Hammadi Codex I. Gnostic theology was close to Logos-centred Christology. The Gnostic statements also contain many other references to ecclesiastical theology. The author of Tractatus Tripartitus was clearly influenced by Church theology, but some ideas were later abandoned by the official doctrine of the Church.

Key words: Christology; Docetism; Christian Gnostics; the doctrine of two natures.

\section{Translated by Rafat Augustyn}

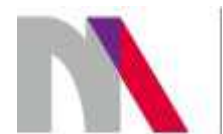

The preparation of the English version of Roczniki Humanistyczne (Annals of Arts) and its publication in electronic databases was financed under contract no. 836/P-DUN/2018 from the resources of the Minister of Science and Higher Education for the popularization of science. 